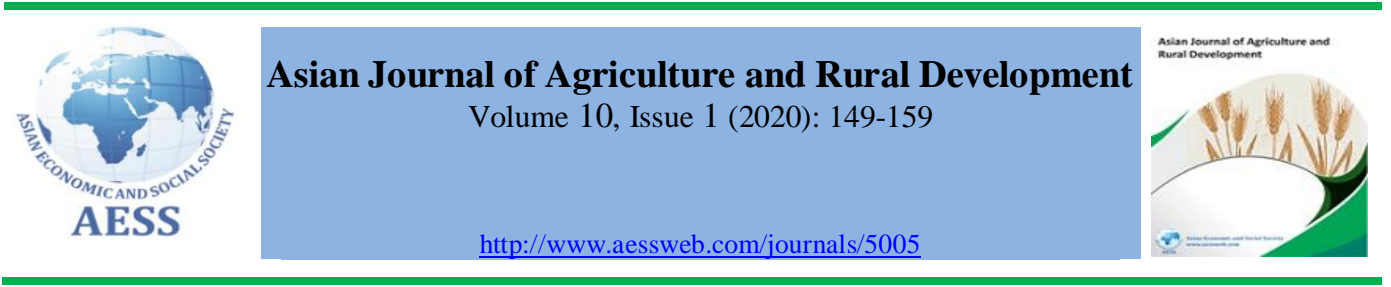

\title{
FIELD EVALUATION OF PRE-EMERGENCE APPLICATION OF SELECTED HERBICIDES FOR OKRA TOLERANCE AND GROWTH IN ASABA, NIGERIA
}

\author{
Obiazi, Christian \\ Chukuka ${ }^{\mathrm{a}}$,
}

Tijani-Eniola, Hassan ${ }^{\mathrm{b}}$,

a Department of Agronomy, Delta State University, Asaba Campus, Asaba, Nigeria

${ }^{\mathrm{b}}$ Department of Agronomy, University of Ibadan, Ibadan, Nigeria

Olaniyi, Olalekan Wasiu ${ }^{\mathrm{b}}$

\section{ARTICLE HISTORY:}

Received: 30-Dec-2019

Accepted: 09-Mar-2020

Online Available: 02-Apr2020

\section{Keywords:}

Herbicide screening, Metholachlor+atrazine, Okra,

Pendimethalin,

Weed control

\begin{abstract}
Okra productivity is reduced by weed interference. Farmers rely on expensive and highly labour intensive manual weeding. Herbicides reduce labour involvement and cost of weed control. Few herbicides tagged for okra production are scarce. The key objectives of this study are to determine the tolerance of okra to some widely used herbicides and evaluate the growth performance of okra in the selected herbicides. The average phytotoxicity levels of each of the herbicides for 2013 and 2014 field trials were in the order of zero in pendimethalin at $2.0 \mathrm{~kg}$ a.i./ha, 4.2 in metholachlor+atrazine at $2.64 \mathrm{~kg}$ a.i./ha and 5.5 in atrazine at $3.0 \mathrm{~kg}$ a.i./ha, on a 0-10 scale. Okra stands establishment was (95.2\%) in pendimethalin and (93.1\%) in hoe-weeded plots, these were significantly greater than $62.8 \%$ and $56.9 \%$ obtained in metholachlor+atrazine at 2.64 $\mathrm{kg}$ a.i./ha and atrazine at $3.0 \mathrm{~kg}$ a.i./ha, respectively. Hoe-weeded plots had shoot dry weight of $7.9 \mathrm{~g} / \mathrm{plant}$ which was similar to $7.3 \mathrm{~g} / \mathrm{plant}$ obtained in pendimethalin treated plots; these were significantly greater than 4.1 $\mathrm{g} /$ plant obtained in plots that received atrazine. Pendimethalin which caused no phytotoxic effect on okra and provided enhanced stand establishment and growth comparable with hoe-weeded should be listed for okra production.
\end{abstract}

\section{Contribution/ Originality}

The study has substantiated that pendimethalin should be added to the list of herbicides for okra (Abelmoschus esculentus L. Moench) production. It also opens up the possibility for farmers and researchers to start considering planting okra in mixture with other crops where pendimethalin is used. Because pendimethalin is widely used for weed control in other crops in the place of the study, scarcity of the herbicide at critical moments of need may be uncommon. The paper has never been published before or presently submitted anywhere for this purpose.

DOI: 10.18488/journal.1005/2020.10.1/1005.1.149.159

ISSN (P): 2304-1455/ISSN (E):2224-4433

How to cite: Obiazi, Christian Chukuka, Tijani-Eniola, Hassan and Olaniyi, Olalekan Wasiu (2020). Field evaluation of pre-emergence application of selected herbicides for okra tolerance and growth in Asaba, Nigeria. Asian Journal of Agriculture and Rural Development, 10(1), 149-159.

(C) 2020 Asian Economic and Social Society. All rights reserved. 


\section{INTRODUCTION}

Okra (Abelmoschus esculentus (L.) Moench is widely produced in Africa (Kochhar, 1986), rich in vitamin C (Adeboye and Oputa, 1996), with high levels of iodine (Philip et al., 2010) and suffers drastic yield reduction in okra fresh pod yield due to uncontrolled weed interference. Adeyemi et al. (2014) reported loss in okra fresh pod yield of 50.7\% due to uncontrolled weed infestation. Average yield reduction of $91.1 \%$ due to season long interference of weed with okra was reported by Awodoyin and Olubode (2009). Least crop yield is mostly obtained from plots which were not given any form of weeding. Dada and Fayiminnu (2010) observed the least okra fresh pod yield in un-weeded plots. Management of weeds in the farm requires high costs and labour input which constitute a major problem in crop production (Aneghen et al., 2010). Obiazi and Ojobor (2013) addressed the problem of high costs and labour input in weed management by suggesting the use of herbicides among other solutions. Osipitan (2017) noted that an important and relatively less costly weed control option is chemical weed control; it involves the use of different herbicides applied as pre and post-emergence of crops. Adigun et al. (2018) suggested that farmers can reduce the problem of hoe weeding and reduce labour input, based on the results of their studies, with the use of pre-emergence herbicides for weed control in okra farms. Imoloame (2017) reported that manual weeding is very strenuous and results in a lot of drudgery and concluded from his study of different herbicide mixtures and manual weed control method in maize that chemical weed control is a practical and economic alternative to hand weeding if herbicide is applied correctly and that it could prevent weed infestation from planting to harvesting. Atrazine is one of the most widely used $\mathrm{S}$-triaxine herbicides in the tropics. Atrazine is sold as a sole component for herbicide formulation and as a component of several formulated mixtures with such other herbicides as metolachlor and sold as primextra or primagram. Atrazine is also used in a formulated mixture with prometryn and it is sold as primaze $80 \mathrm{~W}$ (Akobundu, 1987). The herbicide atrazine is one of the most commonly applied pesticides in the world (Hayes et al., 2010). However, most herbicides recommended for weed control in okra such as diphenamid, fluchloralin, prometryne and trifluralin (Akobundu, 1987; NACWC, 1994) are not readily available. Dittmar and Stall (2014) observed that herbicides recommended for weed control in okra are scarce. Pendimethalin has been part of the recommended herbicides for weed control in cowpea and soybean (NACWC, 1994). Timsina et al. (2020) revealed that the application of pre-emergence herbicides, pendimethalin, supplemented with hand weeding was found to be effective in reducing the weed severity and improves rice growth and yield attributes. Atrazine is a very common herbicide for weed control in arable crops; it is used alone for weed control in maize and also used in combination with other herbicides such as metholachlor to form formulations like Primextra for the control of weeds in maize, cassava and yam (NACWC, 1994). There is therefore the need to assess okra tolerance among some herbicides that have consistently controlled weed effectively in widely cultivated crops in rainforest ecological zones. Pendimethalin, metolachlor + atrazine, and atrazine are effective for pre-emergence weed control in soybean, cassava and maize respectively in the rainforest ecological zone of Nigeria. The study was set up to evaluate okra tolerance and weed control effectiveness of pendimethalin, metolachlor+atrazine and atrazine in okra production.

\section{MATERIALS AND METHODS}

Field experiment was carried out in the Department of Agronomy, Delta State University, Asaba Campus, Asaba, Nigeria in the rainy seasons of 2013 and 2014 at the Teaching and Research Farm located in Latitude $6^{0} 14^{1} \mathrm{~N}$, Longitute $6^{0} 49^{1} \mathrm{E}$, southern Nigeria in the rainforest agro-ecological zone, with rainfall from April to November with peaks in June and September.

The treatment consisted of pre-emergence applications of pendimethalin at $2 \mathrm{~kg}$ a.i./ha, metolachlor+atrazine $(2: 1)$ at $2.64 \mathrm{~kg}$ a.i./ha and atrazine at $3 \mathrm{~kg}$ a.i./ha. Hoe-weeded and unweeded plots served as controls. Hoe-weeded control plots were weeded at three and six Weeks After Sowing (WAS), while the un-weeded plots were left un-weeded throughout the experiment. 
The experiment evaluated the growth of the okra plant as influenced by the pre-emergence application of pendimethalin, metolachlor + atrazine (2:1) and atrazine. The treatments and the controls were laid out in a Randomized Complete Block Design (RCBD) and replicated thrice. Each plot measured $2.0 \times 2.0 \mathrm{~m}$ with a space of $1 \mathrm{~m}$ separating plots within a replicate. Contiguous blocks were separated by $1.5 \mathrm{~m}$ space. The test crop was a commonly grown local okra cultivar, Ozigolo, purchased from Oki market in Agbor, Nigeria. The Okra seeds were soaked in water overnight, the following morning the seeds were removed from the water and air dried under shade and treated with Apron star which contained both fungicide and insecticide for protection against diseases and pests. Vegetation was slashed with cutlass and tree stumps manually removed using hoe, spade and pick axe.

Okra seeds were sown on the flat at an average planting depth of $2 \mathrm{~cm}$ at a spacing of $50 \mathrm{~cm}$ by $50 \mathrm{~cm}$, as used by Afolayan (1997) with 16 stands per plot and a population density of 40,000 plants per hectare. Three seeds of okra were sown per stand and thinned to one seedling per hill at 3 WAS. The soils were sandy loam, adequate in $\mathrm{P}$ and $\mathrm{K}$ and had a total $\mathrm{N}$ of 1.1 and $1, \mathrm{pH}$ value of 5.9 and 6 in 2013 and 2014, respectively. The rate of 50kg N/ha was applied in the form of urea in two equal split doses of placement to okra stands at three and six weeks after sowing. In 2013 the experiment was established on the 10th of May, in the following year, the planting of okra and preemergence application of the herbicides was carried out on the 6th of May, 2014. A CP knapsack sprayer fitted with polijet nozzle delivering 265 1/ha, was used to apply the pre-emergence herbicides.

Pests in the okra plants were controlled by spraying cypermethrin at the rate of $1 \mathrm{ml}$ of cypermethrin per litre of water at 3,5 and 7 weeks after sowing. Four okra stands were tagged within the plots, ensuring that the border rows were excluded, to collect data on the effect of preemergence herbicide treatments on okra performance. Data taken included phytotoxicity rating of the herbicide treatments on okra at 3 WAS, ' 0 ' to ' 10 ' scale was used, ' 0 ' means absence of phytotoxicity effect and ' 10 ' signifies death of the okra plant. Other data collected were the extent of okra stand survival, number of leaves per plant, stem diameter, stem height and shoot dry weight at eight weeks after sowing.

Weed control efficiency of the herbicides was assessed by comparing weed biomass of various treatments with their respective weedy control at 4, 6 and 8 WAS using a quadrat of $50 \mathrm{~cm}$ by $50 \mathrm{~cm}$ dimension. Identification and naming of weeds were done using Akobundu and Agyakwa (1987).

The Weed control efficiency calculation was based on the technique suggested by Prachand et al. (2015) as follows:

$$
W C E(\%)=\frac{D W C-D W T}{D W C} \times \frac{100}{1}
$$

Where, WCE $(\%)=$ Weed Control Efficiency

DWC $=$ dry matter of weed in control plot and

DWT $=$ dry matter of weed in treated plots.

Data concerning okra population per plot and weed dry weight were transformed to square root scale of $\sqrt{ } x+0.5$ and analyzed as suggest by (Little and Hills, 1978).

In respect of the weed biomass, a quadrant of $50 \mathrm{~cm}$ by $50 \mathrm{~cm}$ dimension was randomly placed in two locations per plot and all the weeds found within the quadrant were collected and dried in the oven at $70^{\circ} \mathrm{C}$ to constant weight. Collected data were subjected to Analysis of Variance (ANOVA) and the treatment means were compared using Duncan's Multiple Range Test at 5\% level of probability (Gomez and Gomez, 1984). 


\section{RESULTS}

\subsection{Phytotoxicity}

Significant phytotoxic effects were observed on okra plants grown in plots treated with pendimethalin, metholachlor + atrazine and atrazine (Table 1). Okra grew in plots that received pre-emergence application of pendimethalin sprayed at $2 \mathrm{~kg}$ a.i. /ha did not show phytotoxic effect on the okra plants.

Table 1: Effects of pre-emergence herbicide applications on phytotoxicity rating and number of leaves per okra plants at eight weeks growth stage

\begin{tabular}{lcccccc}
\hline \multirow{2}{*}{ Treatment } & \multicolumn{3}{c}{ Phytotoxicity rating (\%) } & \multicolumn{3}{c}{ Number of leaves / plant } \\
& $\mathbf{2 0 1 3}$ & $\mathbf{2 0 1 4}$ & Average & $\mathbf{2 0 1 3}$ & $\mathbf{2 0 1 4}$ & Average \\
\hline Pendimethalin at $2.0 \mathrm{~kg}$ a.i./ha & $0.0 \mathrm{c}$ & $0.0 \mathrm{~b}$ & $0.0 \mathrm{c}$ & $9.72 \mathrm{a}$ & $8.92 \mathrm{ab}$ & $9.32 \mathrm{a}$ \\
Metholachlor + atrazine (2:1) at $2.64 \mathrm{~kg}$ & $5.4 \mathrm{~b}$ & $2.9 \mathrm{a}$ & $4.2 \mathrm{~b}$ & $6.17 \mathrm{c}$ & $8.58 \mathrm{ab}$ & $7.38 \mathrm{bc}$ \\
a.i./ha & $6.8 \mathrm{a}$ & $4.2 \mathrm{a}$ & $5.5 \mathrm{a}$ & $4.93 \mathrm{~d}$ & $7.91 \mathrm{~b}$ & $6.42 \mathrm{c}$ \\
Atrazine at $3.0 \mathrm{~kg}$ a.i./ha & $0.0 \mathrm{c}$ & $0.0 \mathrm{~b}$ & $0.0 \mathrm{c}$ & $10.22 \mathrm{a}$ & $9.12 \mathrm{a}$ & $10.02 \mathrm{a}$ \\
Hoe-weeded at 3 and 6 WAS & $0.0 \mathrm{c}$ & $0.0 \mathrm{~b}$ & $0.0 \mathrm{c}$ & $6.33 \mathrm{~b}$ & $9.31 \mathrm{a}$ & $7.82 \mathrm{~b}$ \\
Weedy & 0.57 & 0.46 & 0.32 & 1.11 & 1.29 & 0.48 \\
$\mathrm{SE} \pm(0.05)$ & &
\end{tabular}

Note: Means followed by the same letter(s) within a column in the same year are not significantly different at $5 \%$ level of probability using DMRT

Okra grown in plots treated with metholachlor + atrazine at $2.64 \mathrm{~kg}$ a.i. $/ \mathrm{ha}$ and atrazine at $3 \mathrm{~kg}$ a.i./ha displayed phytotoxic effects, in each of the years, atrazine was significantly more phytotoxic on okra than metholachlor + atrazine. Atrazine had 6.8 and 4.2 phytotoxic rates on okra seedlings at three weeks after sowing in the first and second years, respectively; these were significantly greater than 5.5 and 2.9 levels of phytotoxicity on okra by metholachlor + atrazine in 2013 and 2014, respectively. Atrazine used at $3 \mathrm{~kg}$ a.i./ha was more phytotoxic on okra than metholachlor + atrazine used at $2.64 \mathrm{~kg}$ a.i./ha. Significant phytotoxic effects were observed at $3 \mathrm{WAS}$ on okra plants grown in plots treated with pre-emergence herbicide.

Okra grown in plots that received pre-emergence application of pendilin (pendimethalin) at $2 \mathrm{~kg}$ a.i./ha did not show any phytotoxic effect; okra grown in plots treated with atrazine at $3 \mathrm{~kg}$ a.i./ha showed the highest phytotoxicity. Primextra (metolachlor+atrazine used at $2.64 \mathrm{~kg}$ a.i./ha was less injurious to okra plant than atrazine used at $3 \mathrm{~kg}$ a.i./ha in this study. Okra showed sensitivity to preemergence application of atrazine. On the average, the phytotoxicity rating of the herbicides was atrazine $>$ metholachlor+atrazine $>$ pendimethalin.

\subsection{Effects of weed control treatments on the number of leaves per plant, plant height and stem diameter of okra}

Atrazine treated plots had 4.93 and 7.91 leaves per plant in 2013 and 2014, respectively (Table 1), the plots treated with atrazine had significantly the least number of leaves per plant in the first year, however in 2014, the value (7.91) in metholachlor + atrazine was comparable to the number of leaves per plant grown in plots treated with pendimethalin (8.92) and metholachlor + atrazine (8.58), respectively. The number of leaves per plant in 2014 ranged from 7.91 (atrazine) to 9.12 (hoe-weeded plots), the hoe-weeded plots had significantly greater number of leaves per plant than the ones grown in atrazine treated plots. The mean number of leaves per plant was in the order of Hoe-weeding (10.02) = Pendimethalin (9.32) > Weedy (7.82) $=$ Metholachlor + Atrazine $(7.38)=$ Atrazine (6.42). 
Okra grown in pendimethalin treated plots were tallest $(63.8 \mathrm{~cm})$ in 2013 as well as in 2014 $(65.6 \mathrm{~cm})$. The height of okra grown in the other plots ranged from $19.7 \mathrm{~cm}$ to $58.1 \mathrm{~cm}$ for both years (Table 2). The shortest okra stems were found in un-weeded plots; however, okra plants in plots treated with metholachlor + atrazine in 2014 were not significantly different in height from okra in untreated plots. On the average, okra plants grown in pendimethalin treated plots were tallest while the ones grown in atrazine treated plots were the shortest.

Table 2: Effects of pre-emergence herbicide applications on stem height and stem diameter in okra plants at eight weeks growth stage

\begin{tabular}{lcccccc}
\hline \multirow{2}{*}{ Treatment } & \multicolumn{3}{c}{ Stem height $(\mathbf{c m})$} & \multicolumn{3}{c}{ Stem diameter (cm) } \\
& $\mathbf{2 0 1 3}$ & $\mathbf{2 0 1 4}$ & Average & $\mathbf{2 0 1 3}$ & $\mathbf{2 0 1 4}$ & Average \\
\hline Pendimethalin at 2kg a.i./ha & $63.8 \mathrm{a}$ & $65.6 \mathrm{a}$ & $64.7 \mathrm{a}$ & $2.70 \mathrm{a}$ & $2.68 \mathrm{a}$ & $2.69 \mathrm{a}$ \\
Metholachlor + atrazine (2:1) at 2.64 kg & $25.7 \mathrm{~d}$ & $35.9 \mathrm{c}$ & $30.8 \mathrm{~d}$ & $0.93 \mathrm{~b}$ & $1.17 \mathrm{~b}$ & $1.05 \mathrm{~b}$ \\
a.i./ha & $21.5 \mathrm{e}$ & $19.7 \mathrm{~d}$ & $20.6 \mathrm{e}$ & $0.87 \mathrm{~b}$ & $0.93 \mathrm{~b}$ & $0.90 \mathrm{~b}$ \\
Atrazine at 3kg a.i./ha & $50.9 \mathrm{~b}$ & $58.1 \mathrm{~b}$ & $54.5 \mathrm{~b}$ & $2.92 \mathrm{a}$ & $3.10 \mathrm{a}$ & $3.01 \mathrm{a}$ \\
Hoe-weeded at 3 and 6 WAS & $37.2 \mathrm{c}$ & $39.8 \mathrm{c}$ & $38.5 \mathrm{c}$ & $0.90 \mathrm{~b}$ & $0.89 \mathrm{~b}$ & $0.90 \mathrm{~b}$ \\
Weedy & 2.81 & 3.92 & 2.23 & 0.31 & 0.32 & 0.20 \\
SE \pm &
\end{tabular}

Note: Means followed by the same letter(s) within a column in the same year are not significantly different at $5 \%$ level of probability using DMRT

Thickest stems $(3.10 \mathrm{~cm})$ were produced in hoe-weeded plots in 2014, and the thinnest stems $(0.87 \mathrm{~cm})$ were grown in plots that were treated with atrazine in 2013 (Table 2). Okra plants grown in plots treated to pendimethalin had similar stem diameter with the ones grown in hoe-weeded plots in both years. Each of them had an average stem thickness which was more than $2.60 \mathrm{~cm}$ thick. Okra plants grown in plots treated to metholachlor +atrazine and atrazine were similar to that of un-weeded control; their stem diameters ranged from 0.87 to $1.17 \mathrm{~cm}$.

Okra plants had very few numbers of branches per plant at eight weeks after sowing with maximum of two per plant on plots hoe-weeded twice in 2013 and no branches in plots sprayed with metholachlor + atrazine, atrazine and in the untreated plots in the two trials (Table 3). Okra plants in the plots treated with pendimethalin produced $1.0-1.3$ branches comparable to 2.0 and 1.8 obtained in plots that received two hoe-weeding in 2013 and 2014, respectively.

Table 3: Effects of pre-emergence herbicide applications on stem height and stem diameter in okra plants at eight weeks growth stage

\begin{tabular}{lccc}
\hline Treatment & \multicolumn{3}{c}{ Number of braches/plant } \\
\hline Pendimethalin at 2kg a.i./ha & $1.0 \mathrm{a}$ & $1.3 \mathrm{a}$ & Average \\
Metholachlor + atrazine (2:1) at & $0.0 \mathrm{~b}$ & $0.0 \mathrm{~b}$ & $1.2 \mathrm{a}$ \\
2.64 kg a.i./ha & $0.0 \mathrm{~b}$ & $0.0 \mathrm{~b}$ & $0.0 \mathrm{~b}$ \\
Atrazine at 3kg a.i./ha & $2.0 \mathrm{a}$ & $1.8 \mathrm{a}$ & $0.0 \mathrm{~b}$ \\
Hoe-weeded at 3 and 6 WAS & $0.0 \mathrm{~b}$ & $0.0 \mathrm{~b}$ & $1.9 \mathrm{a}$ \\
Weedy & 0.36 & 0.28 & $0.0 \mathrm{~b}$ \\
SE \pm & & 0.94 \\
\hline
\end{tabular}

Note: Means followed by the same letter(s) within a column in the same year are not significantly different at $5 \%$ level of probability using DMRT

\subsection{Okra stand establishment and shoot biomass}

Pre-emergence herbicide applications had a significant effect on okra stand establishment (Figure 1). Average okra stand survival ranged from $57.1 \%$ in atrazine treated plots to $95.2 \%$ in 
pendimethalin treated plots. Highest okra stand survival among the treated plots was in pendimethalin plots which was significantly greater than what was recorded in plots treated with metholachlor + atrazine or atrazine. Okra had similar establishment level in metholachlor + atrazine $(62.8 \%)$ and atrazine $(57.1 \%)$ treated plots. The mean highest level of the establishment among the treated plots which were $(95.2 \%)$ pendimethalin was similar to $93.1 \%$ (hoe-weeded control) and $92.2 \%$ (weedy control).

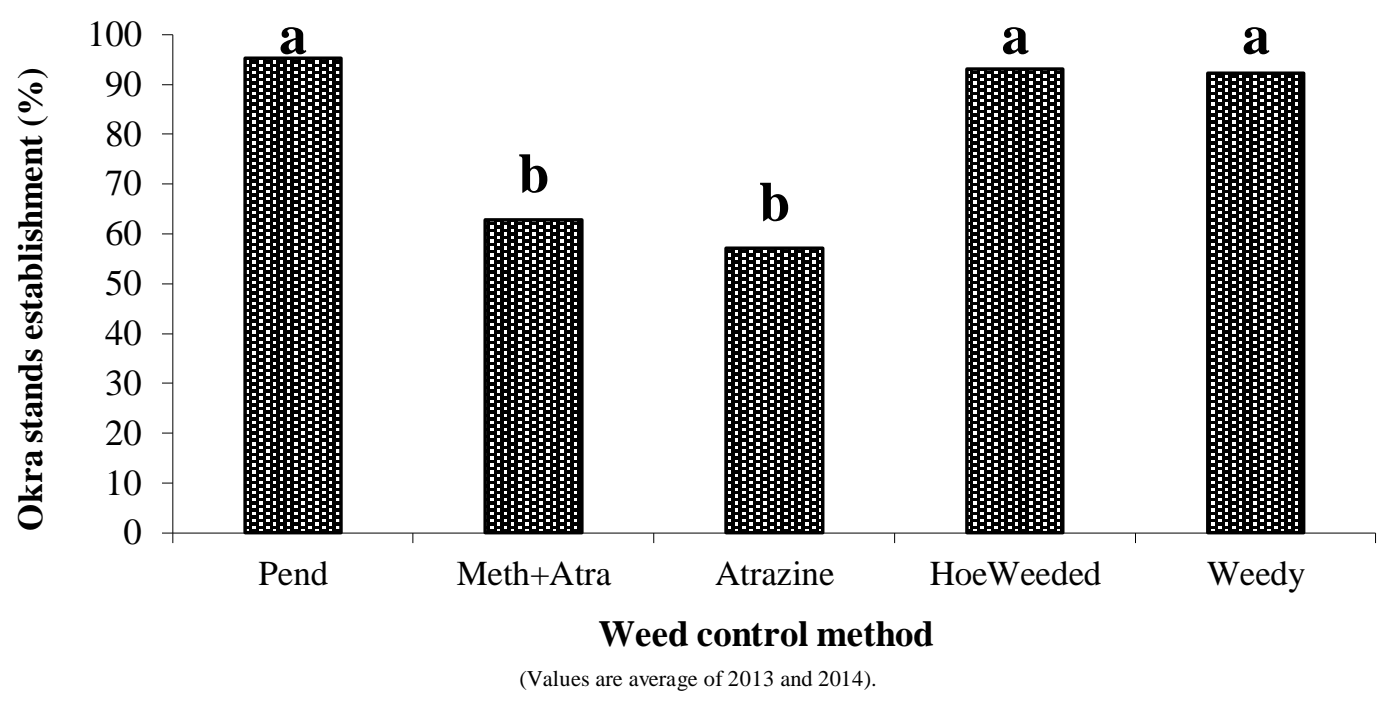

Figure 1: Okra stands establishment as influenced by pre-emergence application of herbicides

Note: Bars bearing the same letter are not significantly different at 5\% level of probability

Pend $=$ Pendimethalin, Meth+Atra $=$ Metholachlor + Atrazine, Hoe Weeded $=$ Hoe weeded at 3 and 6 Weeks after sowing and Weedy $=$ Un-weeded control

The greatest shoot dry weight was produced in plots that were hoe-weeded at three and six weeks after sowing with average shoot biomass of $7.9 \mathrm{~g} / \mathrm{plant}$, this was similar to $7.3 \mathrm{~g} /$ plant obtained in plots that received pre-emergence application of pendimethalin, the least shoot biomass was observed in okra grown in weedy plots (3.3g/plant). Untreated plots had the least shoot biomass of $3.3 \mathrm{~g} /$ plant which was not significantly different from what was obtained in plots treated to atrazine which had $4.1 \mathrm{~g} / \mathrm{plant}$ as average shoot biomass.

\subsection{Weed biomass and weed control efficiency}

Pre-emergence application of pendimethalin, atrazine and metholachlor+atrazine significantly reduced weed biomass compared with the weedy check at 4, 6 and 8 WAS in both 2013 and 2014 (Table 4). At 4 and 6 WAS all the pre-emergence treatments had similar weed biomass which was comparable with those of hoe-weeded control plots in both years. Hoe-weeded control plots at 8 WAS had significantly less weed biomass than any of the plots that received pre-emergence herbicide application in both years.

Weed control efficiency (WCE) of the three pre-emergence herbicides was similar at 4 and 6 WAS during both years of experimentation (Table 4). The three pre-emergence herbicides and hoeweeded control had superior WCE than weedy check at 4, 6 and 8 WAS. At 8 WAS, hoe-weeded control had greater WCE than any of the pre-emergence herbicides (Table 4). 
Table 4: Effects of pre-emergence herbicide applications on weed biomass and weed control efficiency in okra plots

\begin{tabular}{|c|c|c|c|c|c|c|}
\hline \multirow{2}{*}{ Treatment } & \multicolumn{3}{|c|}{ Weed biomass $\left(\mathrm{g} / \mathrm{m}^{2}\right)$} & \multicolumn{3}{|c|}{ Weed control efficiency $(\%)$} \\
\hline & $4 \mathrm{WAS}^{*}$ & $6 \mathrm{WAS}$ & 8 WAS & 4 WAS & $6 \mathrm{WAS}$ & 8 WAS \\
\hline \multicolumn{7}{|l|}{2013} \\
\hline $\begin{array}{l}\text { Pendimethalin at } 2 \mathrm{~kg} \\
\text { a.i./ha }\end{array}$ & $1.6 b$ & $16.3 b$ & $63.4 b$ & $92.12 \mathrm{a}$ & $77.52 b$ & $47.56 b$ \\
\hline $\begin{array}{l}\text { Metholachlor + atrazine } \\
(2: 1) \text { at } 2.64 \mathrm{~kg} \text { a.i./ha }\end{array}$ & $1.7 \mathrm{~b}$ & $14.6 b$ & $57.2 \mathrm{c}$ & $91.63 a$ & $79.86 \mathrm{~b}$ & $52.73 b$ \\
\hline Atrazine at $3 \mathrm{~kg}$ a.i. $/ \mathrm{ha}$ & $1.9 \mathrm{~b}$ & $15.0 \mathrm{~b}$ & $59.8 \mathrm{bc}$ & $90.64 a$ & $79.31 \mathrm{~b}$ & $50.53 b$ \\
\hline $\begin{array}{l}\text { Hoe-weeded at } 3 \text { and } 6 \\
\text { WAS }\end{array}$ & $1.3 b$ & $12.9 \mathrm{~b}$ & $13.3 \mathrm{~d}$ & $93.60 \mathrm{a}$ & $82.21 \mathrm{~b}$ & 89.01a \\
\hline Weedy control & $20.3 \mathrm{a}$ & $72.5 \mathrm{a}$ & $120.9 a$ & $0.00 \mathrm{~b}$ & $0.00 \mathrm{c}$ & $0.00 \mathrm{c}$ \\
\hline $\begin{array}{l}\mathrm{SE} \pm \\
2014\end{array}$ & 1.27 & 3.88 & 4.57 & 3.70 & 4.90 & 4.51 \\
\hline $\begin{array}{l}\text { Pendimethalin at } 2 \mathrm{~kg} \\
\text { a.i./ha }\end{array}$ & $2.4 \mathrm{~b}$ & $13.8 \mathrm{~b}$ & $65.7 b$ & $87.78 \mathrm{a}$ & $81.70 b$ & $40.26 \mathrm{c}$ \\
\hline $\begin{array}{l}\text { Metholachlor }+ \text { atrazine } \\
(2: 1) \text { at } 2.64 \mathrm{~kg} \text { a.i. } / \mathrm{ha}\end{array}$ & $2.0 \mathrm{~b}$ & $16.3 b$ & $55.3 b$ & $90.95 a$ & $78.38 b$ & $49.71 b$ \\
\hline Atrazine at $3 \mathrm{~kg}$ a.i./ha & $2.1 b$ & $15.2 b$ & $56.9 \mathrm{c}$ & $90.50 \mathrm{a}$ & $79.84 b$ & $48.26 \mathrm{~b}$ \\
\hline $\begin{array}{l}\text { Hoe-weeded at } 3 \text { and } 6 \\
\text { WAS }\end{array}$ & $2.5 b$ & $11.6 \mathrm{~b}$ & $14.2 \mathrm{~d}$ & $88.69 a$ & $84.62 b$ & $87.10 \mathrm{a}$ \\
\hline Weedy & $22.1 \mathrm{a}$ & $75.4 a$ & $110.0 \mathrm{a}$ & $0.00 \mathrm{~b}$ & $0.00 \mathrm{c}$ & $0.00 \mathrm{~d}$ \\
\hline $\mathrm{SE} \pm$ & 0.80 & 2.58 & 11.44 & 4.14 & 6.52 & 5.53 \\
\hline
\end{tabular}

Note: Means followed by the same letter(s) within a column in the same year are not significantly different at $5 \%$ level of probability using DMRT

WAS* = Weeks After Sowing

\subsection{Weed percentage distribution in okra plots}

There were generally more broadleaf weed species than grass weed species, and grass weed species occurred more than sedges in the plots where the study was carried out. Only Spigellia anthelmia (an annual broadleaf weed species) and Mariscus alternifolius (perennial sedge) were found in all the plots treated with pre-emergence herbicides and the weedy plots. Twenty weed species were found in 2013 while twenty two occurred in 2014 (Tables 5 and 6). Solanum nigrum Linn and Triumfetta rhomboidea Jacq which were not present in okra plots in 2013 were found only in okra plots that were hoe-weeded and the ones that received $2 \mathrm{~kg}$ a.i./ha of butachlor, respectively, in 2014. Mariscus alternifolius were the only sedge weed species present in the okra plots. There were generally more broadleaf weed species than grass weed species in the okra plots; the broadleaf weeds were 15 in 2013 and 16 in 2014 . There were only four grass weed species observed in the experiment in both years.

Table 5: Percentage distribution of weeds in okra plot in 2013

\begin{tabular}{|c|c|c|c|c|c|c|}
\hline \multirow{2}{*}{$\begin{array}{l}\text { Weed types in } 2013 \\
\text { Annual broadleaves }\end{array}$} & \multirow[t]{2}{*}{ Family } & \multicolumn{5}{|c|}{ Herbicide rates (kg a.i./ha) Meth+ } \\
\hline & & $\begin{array}{l}\text { Pend } \\
(2.0)\end{array}$ & $\begin{array}{l}\text { Atra } \\
(3.6)\end{array}$ & $\begin{array}{l}\text { Atra } \\
(3.3)\end{array}$ & $\begin{array}{c}\text { Hoe } \\
\text { Weeded }\end{array}$ & $\begin{array}{c}\text { Weedy } \\
-\end{array}$ \\
\hline Ageratum conyzoides Linn. & Asteraceae & 0.0 & 0.0 & 6.6 & 12.5 & 0.0 \\
\hline Oldenlendia carymbosa Linn. & Rubiaceae & 0.0 & 0.0 & 0.0 & 0.0 & 1.9 \\
\hline $\begin{array}{l}\text { Phyllantus amarus Schum. } \\
\text { \&Thonn. }\end{array}$ & Euphorbiaceeae & 3.4 & 6.3 & 0.0 & 0.0 & 8.7 \\
\hline $\begin{array}{l}\text { Solenostemon monostachyus } \mathrm{P} \text {. } \\
\text { Beauv. }\end{array}$ & Lamiaceae & 3.1 & 0.0 & 0.0 & 0.0 & 12.2 \\
\hline
\end{tabular}




\begin{tabular}{|c|c|c|c|c|c|c|}
\hline $\begin{array}{l}\text { Spigelia anthelmia Linn. } \\
\text { Perennial broadleaves }\end{array}$ & Loganiaceae & 31.9 & 22.9 & 18.9 & 23.4 & 13.2 \\
\hline $\begin{array}{l}\text { Chromolaena odorata (L) R.M. } \\
\text { King and Robinson }\end{array}$ & Asteraceae & 6.7 & 0.0 & 0.0 & 0.0 & 4.5 \\
\hline Commelina benghalensis (Linn.) & Commelinaceae & 1.6 & 0.0 & 0.0 & 0.0 & 0.0 \\
\hline Desmodium scopiurus Sw. Desv. & Leguminoseae & 4.2 & 0.0 & 12.2 & 1.0 & 1.9 \\
\hline Diodia sarmentosa (Sw.) & Rubiaceae & 5.6 & 0.0 & 0.0 & 0.0 & 0.0 \\
\hline $\begin{array}{l}\text { Ipomoea asarifolia (Desvr.) Roem } \\
\& \text { Schult }\end{array}$ & Convolvulaceae & 3.4 & 0.0 & 3.0 & 0.0 & 3.0 \\
\hline Pouzolzia guineensis Benth & Urticaceae & 0.0 & 0.0 & 0.0 & 0.0 & 0.2 \\
\hline Pueraria phaseoloides & Fabaceae & 5.0 & 0.0 & 2.6 & 0.0 & 0.0 \\
\hline Spermacoe ocymoides Burm f. & Rubiaceae & 0.0 & 0.0 & 5.9 & 0.0 & 0.6 \\
\hline Talinum fruticosum (Jacq.) Willd. & Portulacaceae & 6.3 & 19.6 & 7.6 & 0.0 & 3.7 \\
\hline Triumfetta cordifolia A. Rich & Tiliaceae & 2.3 & 0.0 & 2.8 & 0.0 & 2.8 \\
\hline $\begin{array}{l}\text { Annual grasses Rothboillia } \\
\text { cochinchinensis (Lour.) Claton }\end{array}$ & Poaceae & 0.0 & 0.0 & 2.6 & 0.0 & 0.0 \\
\hline $\begin{array}{l}\text { Setaria barbata (Lam.) Kunnth } \\
\text { Perennial grasses }\end{array}$ & Poaceae & 0.7 & 0.0 & 0.0 & 0.0 & 0.0 \\
\hline Panicum maximum Jacq. & Poaceae & 0.9 & 0.0 & 0.0 & 0.0 & 0.0 \\
\hline $\begin{array}{l}\text { Axonopus compressus (Sw.) P. } \\
\text { Beau V. Perennial sedge }\end{array}$ & Poaceae & 3.1 & 14.6 & 15.0 & 9.6 & 0.0 \\
\hline Mariscus alternifolius Vahl & Cyperaceae & 21.7 & 36.6 & 22.8 & 53.5 & 32.9 \\
\hline
\end{tabular}

Pendimethalin was not phytotoxic to okra in this study in two years. Okra stand survival, number of leaves per plant, stem diameter and shoot dry weight in plots sprayed pendimethalin were similar to what was obtained in plots hoe-weeded at three and six weeks after sowing. Adejoro and Olopha (2013) reported that pendimenthalin at all the rates tested did not affect okra seed germination. Similar outcomes reported by Sah et al. (2018) showed that all the weed control treatments and weed free control apart from pendimethalin at $0.50 \mathrm{~kg} /$ ha (pendimethalin at $0.5,1.0$ and $1.5 \mathrm{~kg}$ a.i./ha were involved in that study) significantly enhanced growth parameters, over weedy check. Similarly, Saleh and Oyinbo (2017) suggested that farmers using hoe weeding and farmer's technologies should be encouraged to adopt pendimethalin technology among others, in order to get more profit.

Table 6: Percentage distribution of weeds in okra plots in 2014

\begin{tabular}{|c|c|c|c|c|c|c|}
\hline \multirow{2}{*}{$\begin{array}{l}\text { Weed types } \\
\text { Annual broadleaves }\end{array}$} & \multirow[t]{2}{*}{ Family } & \multicolumn{5}{|c|}{ Herbicide rates (kg a.i./ha) Meth+ } \\
\hline & & $\begin{array}{l}\text { Pend } \\
(2.0)\end{array}$ & $\begin{array}{l}\text { Atra } \\
(3.6)\end{array}$ & $\begin{array}{l}\text { Atra } \\
(3.3)\end{array}$ & $\begin{array}{c}\text { Hoe } \\
\text { Weeded }\end{array}$ & Weedy \\
\hline$\overline{\text { Ageratum conyzoides Linn. }}$ & Asteraceae & 0.0 & 0.0 & 6.6 & 12.5 & 0.0 \\
\hline Oldenlendia carymbosa Linn. & Rubiaceae & 0.0 & 0.0 & 0.0 & 0.0 & 1.9 \\
\hline $\begin{array}{l}\text { Phyllantus amarus Schum. } \\
\text { \&Thonn. }\end{array}$ & Euphorbiaceeae & 3.4 & 6.3 & 0.0 & 0.0 & 8.7 \\
\hline Solanum nigrum Linn. & Solanaceae & 0.0 & 0.0 & 0.0 & 0.0 & 0.5 \\
\hline $\begin{array}{l}\text { Solenostemon monostachyus P. } \\
\text { Beauv. }\end{array}$ & Lamiaceae & 3.1 & 0.0 & 0.0 & 0.0 & 12.2 \\
\hline $\begin{array}{l}\text { Spigelia anthelmia Linn. } \\
\text { Perennial broadleaves }\end{array}$ & Loganiaceae & 35.9 & 15.5 & 15.8 & 41.8 & 14.4 \\
\hline $\begin{array}{l}\text { Chromolaena odorata (L) R.M. } \\
\text { King and Robinson }\end{array}$ & Asteraceae & 4.7 & 0.0 & 0.0 & 0.0 & 2.6 \\
\hline Commelina benghalensis (Linn.) & Commelinaceae & 1.1 & 0.0 & 0.0 & 0.0 & 0.0 \\
\hline Desmodium scopiurus Sw. Desv. & Leguminoseae & 4.6 & 16.8 & 15.1 & 58.8 & 2.4 \\
\hline Diodia sarmentosa (Sw.) & Rubiaceae & 3.0 & 0.0 & 0.0 & 0.0 & 0.0 \\
\hline
\end{tabular}




\begin{tabular}{|c|c|c|c|c|c|c|}
\hline $\begin{array}{l}\text { Ipomoea asarifolia (Desvr.) } \\
\text { Roem \& Schult }\end{array}$ & Convolvulaceae & 4.0 & 0.0 & 1.4 & 0.0 & 1.1 \\
\hline Pouzolzia guineensis Benth & Urticaceae & 0.0 & 7.7 & 0.0 & 0.0 & 1.3 \\
\hline Pueraria phaseoloides & Fabaceae & 4.0 & 2.1 & 3.5 & 0.0 & 0.0 \\
\hline Spermacoe ocymoides Burm f. & Rubiaceae & 0.0 & 0.0 & 4.5 & 0.0 & 1.6 \\
\hline $\begin{array}{l}\text { Talinum fruticosum (Jacq.) } \\
\text { Willd. }\end{array}$ & Portulacaceae & 5.2 & 9.8 & 7.9 & 0.0 & 4.4 \\
\hline Triumfetta cordifolia A. Rich & Tiliaceae & 2.2 & 0.0 & 1.3 & 0.0 & 2.0 \\
\hline $\begin{array}{l}\text { Triumfetta rhomboidea Jacq. } \\
\text { Annual grasses }\end{array}$ & Tiliaceae & 1.1 & 0.0 & 0.0 & 0.0 & 0.0 \\
\hline $\begin{array}{l}\text { Rothboillia cochinchinensis } \\
\text { (Lour.) Claton }\end{array}$ & Poaceae & 0.0 & 0.0 & 1.2 & 0.0 & 0.0 \\
\hline $\begin{array}{l}\text { Setaria barbata (Lam.) Kunnth } \\
\text { Perennial grasses }\end{array}$ & Poaceae & 1.5 & 0.0 & 0.0 & 0.0 & 1.2 \\
\hline Panicum maximum Jacq. & Poaceae & 1.9 & 0.0 & 0.0 & 0.0 & 0.0 \\
\hline $\begin{array}{l}\text { Axonopus compressus (Sw.) P. } \\
\text { Beau V. Perennial sedge }\end{array}$ & Poaceae & 4.1 & 6.1 & 10.5 & 6.7 & 15.5 \\
\hline Mariscus alternifolius Vahl & Cyperaceae & 20.6 & 35.1 & 30.5 & 17.4 & 34.1 \\
\hline
\end{tabular}

Imoloame and Usman (2018) observed that pendimethalin is one of the herbicides frequently used for weed control in okra production in Malete, Kwara State, Nigeria they adduced that this could be a result of its low price and obtainability in agro-chemical stores all the time. The phytotoxic level of metholachlor + atrazine (primextra) and atrazine to okra was similar. Egwu et al. (2019) reported that the phytotoxicity of primextra to okra was high. Aladesanwa (2005) also reported that atrazine significantly reduced total leaf area of the crop, plant height and the pod fresh weight relative to the control. Okra percentage stand survival, number of leaves per plant and stem diameter were similar in plots treated with metholachlor + atrazine and atrazine, these were significantly less than what obtained in plots treated with pendimethalin and plots hoe-weeded, and were significantly greater than what was obtained in un-weeded plots. However, okra in plots sprayed with metholachlor + atrazine had superior stem height and shoot biomass than what was obtained in plots treated with atrazine. Significant reduction in percentage okra seedlings survival per plot, number of leaves per plant, stem height and diameter, number of branches per plant, shoot biomass, indicating that preemergence application of atrazine at recommended rate of $3 \mathrm{~kg}$ a.i./ha had phytotoxic effects on okra. This is in agreement with the findings of Aladesanwa (2005) who reported the residual phytotoxic activities of atrazine on okra at the recommended dose of $3 \mathrm{~kg}$ a.i./ha. He reported that atrazine significantly $(\mathrm{p}<0.05)$ reduced okra plant height, total leaf area and pod fresh weight relative to the control. The three herbicides had similar weed control efficiency which were superior to what was obtained in un-weeded control plots but less effective at 8 WAS relative to plots hoe-weeded at 3 and 6 WAS.

\section{CONCLUSION}

Okra was tolerant of pendimethalin at $2 \mathrm{~kg}$ a.i./ha, moderately tolerant of metholachlor +atrazine at $2.64 \mathrm{~kg}$ a.i./ha while atrazine at $3 \mathrm{~kg}$ a.i./ha was severely phytotoxic. Three herbicides effectively controlled weed in the environment. Okra was not tolerant to pre-emergence application of atrazine at $3 \mathrm{~kg}$ a.i./ha, there was decrease in okra stand establishment and shoot dry weight relative to what was obtained in the hoe-weeded plots. Atrazine was not suitable for pre-emergence weed control in okra at that $3 \mathrm{~kg}$ a.i./ha. Plots that received pre-emergence application of pedimethalin at $2 \mathrm{~kg}$ a.i./ha had similar okra stand establishment and produced comparable okra shoot dry weight with plots hoe-weeded at three and six weeks after sowing and effectively controlled weed. The suitability of pendimethalin for weed control in okra in the rainforest ecological zone of Asaba, Nigeria has 
therefore been established; pendimethalin should be among the herbicides to be considered for weed control in okra at Asaba, Nigeria.

Funding: This study did not receive any specific financial support.
Competing Interests: The authors declared that they have no conflict of interests.
Contributors/Acknowledgement: All authors participated equally in designing and estimation of current
research.
Views and opinions expressed in this study are the views and opinions of the authors, Asian Journal of
Agriculture and Rural Development shall not be responsible or answerable for any loss, damage or liability
etc. caused in relation to/arising out of the use of the content.

\section{References}

Adeboye, O. C., \& Oputa, C. O. (1996). Effects of galex on growth and fruit nutrient composition of okra (Abelmoschus esculentus L. Moench). Ife Journal of Agriculture, 18(1 and 2), 1-9.

Adejoro, S. A., \& Olopha, P. K. (2013). Weed control in okra (Abelmoschusesculentus (L.) Moench) with pendimethalin and its residual effects on soil physico-chemical properties. Journal of Sustainable Technology, 4(2), 58-65.

Adeyemi, O. R., Fabunmi, T. O., Adedeji, V. O., \& Adigun, J. A. (2014). Effects of time of weed removal and cropping system on weed control and crop performance in okra/Amaranthus Intercrop. American Journal of Experimental Agriculture, 4(12), 1697-1707. doi.org/10.9734/ajea/2014/10232.

Adigun, J. A., Daramola, O., Adeyemi, O. R., Ogungbesan, A., Olorunmaiye, P., \& Osipitan, O. A., (2018). Impact of nitrogen levels and weed control methods on growth and yield of okra (Abelmoschus esculentus (L.) Moench) in the Nigerian Forest-Savanna Transition Zone. Journal of Experimental Agriculture International, 20(2), 1-11.

Afolayan, S. O. (1997). Effects of irrigation frequency on soil moisture potential and fruit yield of okra (Ablmoschus esculentus). In: Proceedings of the $15^{\text {th }}$ Annual Conference of Horticultural Society of Nigeria (HORTSON) 8-11 ${ }^{\text {th }}$ April, National Horticulture Research Institute, Ibadan pp. 104-105.

Akobundu, I. O. (1987). Weed science in the tropics: principles and practices. John Wiley and Sons. 522 pp. Chichester, West Susex, England

Akobundu, I. O., \& Agyakwa, C. W. (1987). A handbok of West African weeds. International Institute of Tropical Agriculture, Oyo Road, Ibadan, Nigeria 194 p.

Aladesanwa, R. D. (2005). Screenhouse evaluation of atrazine for soil residual activity on growth, development and nutritional quality of okra (Abelmoschus esculentus Moench) in southwestern Nigeria. Crop Protection 2 24(10), 927-931.

Aneghen, P. O., Amakiri, M. A., Okpuwaribo, E. E, Wahuwa, T. A. T. \& Mokwuye, M. U. B. (2010). Inga edulis Mart.: A valuable woody legume for weed control in a sustainable agroforestry system. Proceedings of the $34^{\text {th }}$ Annual Conference of the Soil Science Society of Nigeria. Emerging Challenges of Soil Resources in Times of Global Climate Change and Food Crisis. Taiwo, L. B., Oluwatosin, G. A., Adediran, J. A., Are, K. S., Oke, A. O. and Ojeniyi, S. O. (editors). March $22^{\text {nd }}-26^{\text {th }}, 2010$ held at Institute of Agricultural Research and Training, Moor Plantation, Ibadan, Nigeria. Pp 289-293.

Awodoyin, R. O., \& Olubode, O. S. (2009). On field assessment of critical period of weed interference in okra (Abelmoschus esculentus (L.) Moench) field in Ibadan, a rainforestsavanna transition eco-zone of Nigeria. Asian Journal of Food Agriculture-Industry, Special Issue S, 288- 296.

Dada, O. A., \& Fayinminnu, O. O. (2010). Period of weed control in okra (Abelmoschus esculentus (L) Moench) as influenced by varying rates of cattle dung and weeding regimes. Notulae Botanicae Horti Agrobotanici Cluj-Napoca, 38(1) 149-154.

Dittmar, P. J., \& Stall, W. M. (2014). Weed Management in Okra, Document is HS192, one of a series of the Horticultural Sciences Department, UF/IFAS Extension. Original publication 
was dated March 1999. Retrieved March 5, 2019 from EDIS website https://edis.ifas.ufl.edu/wg032.

Egwu, F., Ochekwu, E. B., \& Ogazie, C. A. (2019). Phytotoxicity of Primextra Golg herbicides on groundnut (Arachis hypogeal) and okra (Abelmoschus esculentus L.). Asian Journal of Biological Sciences 12, 518-523. URL: https://sclalert.net/abstract/?dol=ajbs.2019.518.523.

Gomez, K. A., \& Gomez, A. A. (1984). Statistical procedures for agricultural research. A WileyInterscience Publication. John Wiley \& Sons, New York 1984, 689 pp.

Hayes, T. B., Khoury, V., Narayan, A., Nazir, M. , Park, A., Brown, T., Adame, L., Chan, E.., Buchholz, D., Stueve, T., \& Gallipeau, S. 2010. Atrazine induces complete feminization and chemical castration in male African clawed frogs (Xenopus laevis). .Proceedings of the National Academy of Sciences of the United States of America, 107(10), 4612-4617. doi:10.1073/pnas.0909519107.

Imoloame, E. O. (2017). Evaluation of herbicide mixtures and manual weed control method in maize (Zea Mays L.) Production in the Southern Guinea Savanna of Nigeria. Cogent Food and Agriculture, 3, 1-17.

Imoloame, E. O., \& Usman, M. (2018). Weed biomass and productivity of okra (Abelmoshus esculentus (L.) as influenced by spacing and pendimethalin-based weed management. Journal of Agricultural Sciences, 63, 4, 379-398. https://doi.org/10.2298/JAS1804379I.

Kochhar, S. L. (1986). Tropical crops: a textbook of economic botany. $1^{\text {st }}$ Edition, MacMillan Publishers, London. 467pp.

Little, T. M., \& Hills, F. J. (1978). Agricultural experimentation: design and analysis. New York: John Wiley and Sons 368 pp.

NACWC. (1994). National advisory committee on weed control (NACWC). Weed Control Recommendations for Nigeria. Series No. 3. Ibadan. The Department of Agriculture, Federal Ministry of Agriculture $111 \mathrm{pp}$.

Obiazi, C. C., \& Ojobor, S. A. (2013). Production challenges of cassava and prospects. Journal of Biology, Agriculture and Healthcare, 3(14), 31-35.

Osipitan, O. A. (2017). Weed interference and control in cowpea production: a review. Journal of Agricultural Science, 9(12), 11-20.

Philip, C. B., Sajo, A. A., \& Futuless, K. M. (2010). Effects of spacing and NPK fertilizer on the yield and yield components of okra (Abelmoschus esculentus L.) in Mubi, Adamawa State. Journal of Agronomy, 9,131-134.

Prachand, S., Kalhapure, A., \& Kubde, K. J. (2015). Weed management in soybean with pre- and post-emergence herbicides. Indian Journal of Weed Science, 47(2), 163-165.

Sah, D., Heisnam, P., \& Pande, A. K. (2018). Weed management in okra under foot hill conditions of North Eastern Himalaya. Journal of Crop and Weed, 14(1), 201-204.

Saleh, M. K., \& Oyinbo, O. (2017). Rice production under different weed management technologies adopted by rice farmers in Katsina State, Nigeria. Journal of Agricultural Extension, 21(1), 152-168. http://dx.doi.org/10.4314/jae.v21i1.12.

Timsina, D., shrestha, A., \& Thapa, B. (2020). Effectiveness of weed management practices in groundnut (Arachis hypogaea). Journal of Research in Weed Science, 3(2), 120-253. 